\title{
Non-contiguous finished genome sequence of Prevotella timonensis type strain $4401737^{\top}$
}

\author{
Véronique Roux ${ }^{1 *}$, Catherine Robert ${ }^{1}$ and Didier Raoult ${ }^{1}$. \\ ${ }^{1}$ Aix Marseille Université, URMITE, Faculté de médecine, Aix-Marseille Université \\ *Correspondence: Véronique Roux (veronique.roux@univ-amu.fr)
}

Keywords: Prevotella timonensis, Bacteroidetes

\begin{abstract}
Prevotella timonensis strain $4401737^{\top}$ is a member of the genus Prevotella, which contains anaerobic Gram-negative bacteria. It was isolated from a human breast abscess. In this work, we describe a set of features of this organism, together with the complete genome sequence and annotation. The 3,169,464 bp long genome contains 2,746 protein-coding genes and 56 RNA genes, including 3 or 4 rRNA operons.
\end{abstract}

\section{Introduction}

Prevotella timonenis strain $4401737^{\mathrm{T}}$ (CIP $108522^{\mathrm{T}}=$ CCUG $50105^{\mathrm{T}}$ ) is the type strain of $P$. timonensis. This bacterium was isolated from a human breast abscess [1]. The genus Prevotella is comprised of anaerobic Gram-negative bacteria. It currently contains 47 members [2]. Recently, many species of the genus Prevotella have been isolated from human sources, often associated with the oral cavity [3-8], but also from feces [9], amniotic fluid [10], blood cultures, lung abscess pus, broncho-alveolar lavages [11] and pleural fluids [12].

Here we present a summary classification and a set of features for $P$. timonensis, together with the description of the non-contiguous finished genomic sequencing and annotation.

\section{Classification and features}

The 16S rRNA gene sequence of $P$. timonensis strain $4401737^{\mathrm{T}}$ was compared with sequences deposited in the Genbank database, indicating that the initial taxonomic classification is correct.

Figure 1 shows the phylogenetic neighborhood of $P$. timonensis in a $16 \mathrm{~S}$ rRNA based tree.

The bacterium was first characterized in 2004; it was isolated from a 40-year-old woman who underwent a breast abscess puncture. The organism was in the liquid from the punctured abscess and was cultured in the Timone Hospital microbiology laboratory.

Cells are rods $0.8-1.4 \mu \mathrm{m}$ long and $0.3-0.5 \mu \mathrm{m}$ wide and usually occurred singly. Optimal growth of strain $4401737^{\mathrm{T}}$ occurs at $37^{\circ} \mathrm{C}$ with a range for growth between 25 and $37^{\circ} \mathrm{C}$. After 72 hours growth on blood sheep agar at $37^{\circ} \mathrm{C}$, surface colonies are circular, white-greyish, smooth, shiny, nonpigmented and 1-2 $\mathrm{mm}$ in diameter. Carbon sources utilized include ribose, glucose, lactose, maltose and tagatose. Activities of alkaline phosphatase, $\beta$ galactosidase, $\alpha$-glucosidase, $\quad \mathrm{N}$-acetyl- $\beta$-glucosaminidase, $\alpha$ fucosidase, arginine arylamidase, leucyl glycine arylamidase, alanine arylamidase are detected. The fatty acid profile is characterized by the predominance of C14:0 (19.5\%), C16:0 (15.3\%), iso-C14:0 (14\%) and a mixture of C18:2 $\omega 6,9 \mathrm{c}$ and C18:0 (16\%). The size and ultrastructure of cells were determined by negative staining transmission electron microscopy. The rods were 0.8-1.4 $\mu \mathrm{m}$ long and 0.3-0.5 $\mu \mathrm{m}$ wide (Figure 2, Table 1 ).

\section{Genome sequencing and annotation Genome project history}

The organism was selected for sequencing on the basis of its phylogenetic position and 16S rDNA similarity to other members of the genus Prevotella, and is part of study of the new species characterized in our laboratory. A summary of the project information is shown in Table 2. The EMBL accession number is CBQQ010000001 and consists of 148 contigs ( $\geq 500 \mathrm{bp}$ ) and 25 scaffolds $(>1,500$ $\mathrm{bp}$ ). Table 2 shows the project information and its compliance with MIGS version 2.0 standards. 
Table 1. Classification and general features of Prevotella timonensis strain $4401737^{\top}$

\begin{tabular}{|c|c|c|c|}
\hline MIGS ID & Property & Term & Evidence code $^{\mathrm{a}}$ \\
\hline & \multirow{8}{*}{ Current classification } & Domain Bacteria & TAS [14] \\
\hline & & Phylum Bacteroidetes & TAS $[15,16]$ \\
\hline & & Class Bacteroidia & TAS $[15,17]$ \\
\hline & & Order Bacteroidales & TAS $[15,18]$ \\
\hline & & Family Prevotellaceae & TAS $[15,19]$ \\
\hline & & Genus Prevotella & TAS $[20-22]$ \\
\hline & & Species Prevotella timonensis & TAS $[1]$ \\
\hline & & Type strain $4401737^{\top}$ & TAS [1] \\
\hline & Gram stain & Negative & TAS [1] \\
\hline & Cell shape & Rod-shaped & TAS [1] \\
\hline & Motility & Non motile & TAS [1] \\
\hline & Sporulation & Non-sporulating & TAS [1] \\
\hline & Temperature range & Mesophile & TAS [1] \\
\hline & Optimum temperature & $37^{\circ} \mathrm{C}$ & TAS [1] \\
\hline MIGS-6.3 & Salinity & Not reported & \\
\hline \multirow[t]{3}{*}{ MIGS-22 } & Oxygen requirement & Anaerobic & TAS [1] \\
\hline & Carbon source & Glucose, lactose, maltose, ribose, tagatose & TAS [1] \\
\hline & Energy source & Chemoorganotroph & NAS \\
\hline MIGS-6 & Habitat & Host & TAS [1] \\
\hline MIGS-15 & Biotic relationship & Free living & TAS [1] \\
\hline \multirow[t]{3}{*}{ MIGS-14 } & Pathogenicity & Unknown & NAS \\
\hline & Biosafety level & 2 & \\
\hline & Isolation & Human breast abscess & \\
\hline MIGS-4 & Geographic location & Marseille, France & TAS [1] \\
\hline MIGS-5 & Sample collection time & 2004 & TAS [1] \\
\hline MIGS-4.1 & Latitude & $43^{\circ} 18 \mathrm{~N}$ & IDA \\
\hline MIGS-4.1 & Longitude & $5^{\circ} 23 \mathrm{E}$ & IDA \\
\hline MIGS-4.3 & Depth & Surface & IDA \\
\hline MIGS-4.4 & Altitude & $21 \mathrm{~m}$ above sea level & IDA \\
\hline
\end{tabular}

Evidence codes - IDA: Inferred from Direct Assay; TAS: Traceable Author Statement (i.e., a direct report exists in the literature); NAS: Non-traceable Author Statement (i.e., not directly observed for the living, isolated sample, but based on a generally accepted property for the species, or anecdotal evidence). These evidence codes are from the Gene Ontology project [23]. If the evidence is IDA, then the property was directly observed for a live isolate by one of the authors or an expert mentioned in the acknowledgements.

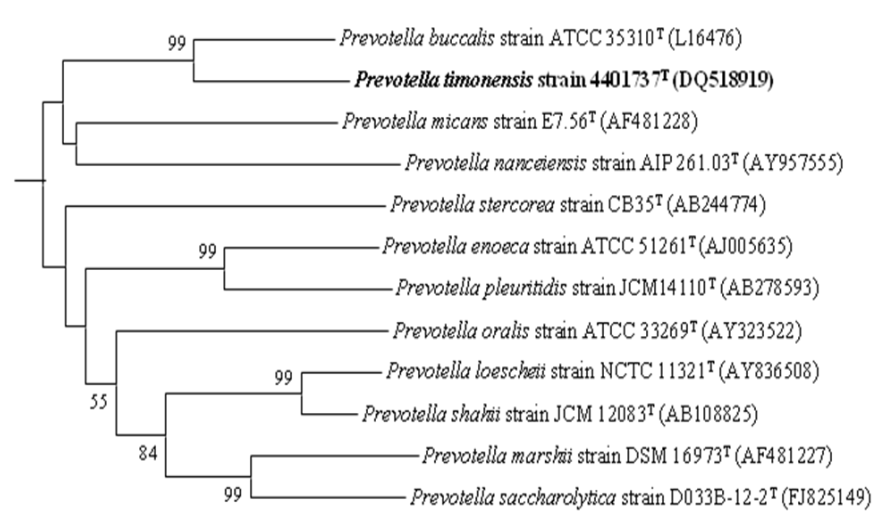

0,02
Figure 1. Part of a phylogenetic tree highlighting the position of Prevotella timonensis strain 4401737T relative to other type strains within the genus Prevotella by comparison of $16 \mathrm{~S}$ rRNA gene sequences. GenBank accession numbers are indicated in parentheses. Sequences were aligned using CLUSTALX, and phylogenetic inferences obtained using the neighbor joining method within the MEGA 5 software [13]. Numbers at the nodes are percentages of bootstrap values ( $\square 50 \%$ ) obtained by repeating the analysis 1,000 times to generate a majority consensus tree. Paraprevotella clara was used as the outgroup (not shown). The scale bar represents 0.002 nucleotide change per nucleotide position. 


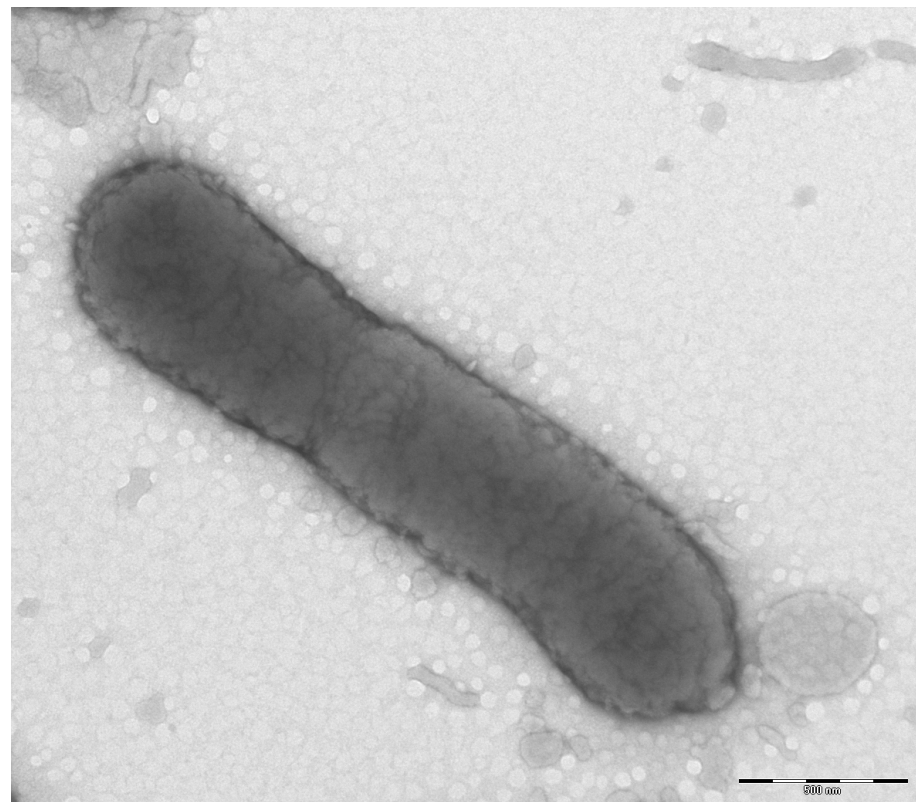

Figure 2. Transmission electron micrograph of P. timonensis strain 4401737T, using a Morgani $268 \mathrm{D}$ (Philips) at an operating voltage of $60 \mathrm{kV}$. The scale bar represents $500 \mu \mathrm{m}$.

Table 2. Project information

\begin{tabular}{lll}
\hline MIGS ID & Property & Term \\
\hline MIGS-31 & Finishing quality & High-quality draft \\
MIGS-28 & Libraries used & One paired end 3-kb library and \\
& & two Shotgun libraries \\
MIGS-29 & Sequencing platforms & 454 GS FLX Titanium \\
MIGS-31.2 & Fold coverage & 78.12× \\
MIGS-30 & Assemblers & Newbler version 2.5.3 \\
MIGS-32 & Gene calling method & Prodigal \\
& EMBL ID & CBQQ010000001 \\
& EMBL Date of Release & June 18, 2013 \\
& Project relevance & Study of new species isolated in the \\
\hline
\end{tabular}

\section{Growth conditions and DNA isolation}

P. timonensis strain 4401737T was grown anaerobically on $5 \%$ sheep blood-enriched Columbia agar at $37^{\circ} \mathrm{C}$. Five petri dishes were spread and colonies resuspended in $3 \mathrm{ml}$ of TE buffer. Three hundred $\mu \mathrm{l}$ of $10 \%$ SDS and $150 \mu \mathrm{l}$ of proteinase K were then added and incubation was performed over-night at $56^{\circ} \mathrm{C}$. The DNA was then extracted using the phenol/chloroform method. The yield and the concentration were measured by the Quant-it Picogreen kit (Invitrogen) on the Genios Tecan fluorometer at $84.3 \mathrm{ng} / \mu \mathrm{l}$.

\section{Genome sequencing and assembly}

Shotgun and 3-kb paired-end sequencing strategies were performed. A shotgun library was constructed with 500 ng of DNA with the GS Rapid library Prep kit (Roche). For the paired-end sequencing, $5 \mu \mathrm{g}$ of
DNA was mechanically fragmented on a Hydroshear device (Digilab) with an enrichment size at 3-4 kb. The DNA fragmentation was visualized using the 2100 BioAnalyzer (Agilent) on a DNA labchip 7500 with an optimal size of $3.7 \mathrm{~kb}$. The library was constructed according to the 454 GS FLX Titanium paired-end protocol. Circularization and nebulization were performed and generated a pattern with an optimal size of $574 \mathrm{bp}$. After PCR amplification through 17 cycles followed by double size selection, the single stranded paired-end library was then quantified using the Genios fluorometer (Tecan) at $1070 \mathrm{pg} / \mu \mathrm{L}$. The library concentration equivalence was calculated as 3.42 x $10^{9}$ molecules $/ \mu \mathrm{L}$. The library was stored at $-20^{\circ} \mathrm{C}$ until further use. Another shotgun library was constructed with $1 \mu \mathrm{g}$ of DNA as described in the 
Roux, et al.

Rapid Library Preparation Method Manual GS FLX+ Series - XL+ except that fragmentation was obtained on Covaris ${ }^{\circledR}$ M220 focused-ultrasonocator ${ }^{\mathrm{TM}}$ instead of on a Hydroshear device.

The shotgun and paired-end libraries obtained with the GS-FLX Titanium technology were clonallyamplified with $1 \mathrm{cpb}$ in 4 SV-emPCR reactions, and $0.5 \mathrm{cpb}$ in $2 \mathrm{SV}$-emPCR reactions with the GS Titanium SV emPCR Kit (Lib-L) v2 (Roche). The yields of the emPCR were $18.7 \%$ and $10.9 \%$, respectively, in the 5 to $20 \%$ range from the Roche procedure. The shotgun library obtained with the GS-FLX+ technology was clonally-amplified with 3 $\mathrm{cpb}$ in 2 SV-emPCR reactions. The yield of the emPCR was $23.95 \%$. Approximately 790,000 beads for the shotgun application and for the $3 \mathrm{~kb}$ paired end were loaded on the GS Titanium PicoTiterPlate PTP Kit 70x75 and sequenced with the GS FLX Titanium Sequencing Kit XLR70 (Roche). The run was performed overnight and then analyzed on the cluster through the gsRunBrowser and Newbler assembler (Roche). A total of 573,130 passed filter wells were obtained and generated $249.97 \mathrm{Mb}$ with an average length of $424 \mathrm{bp}$. The passed filter sequences were assembled using Newbler with $90 \%$ identity and $40 \mathrm{bp}$ as overlap. The final assembly identified 25 scaffolds and 105 large contigs $(>1,500$ bp).

\section{Genome annotation}

Open Reading Frames (ORFs) were predicted using Prodigal [24] with default parameters but the predicted ORFs were excluded if they were spanning a sequencing GAP region. The predicted bacterial protein sequences were searched against the GenBank database [25] and the Clusters of
Orthologous Groups (COG) databases [26] using BLASTP. The tRNAscan-SE tool [27] was used to find tRNA genes, whereas ribosomal RNAs were found by using RNAmmer [28]. Transmembrane domains and signal peptides were predicted using TMHMM [29] and SignalP [30], respectively. ORFans were identified if their BLASTp $E$-value was lower than $1 \mathrm{x}$ $10^{-3}$ for alignment length greater than 80 amino acids. If alignment lengths were smaller than 80 amino acids, we used an $E$-value of $1 \times 10^{-5}$. Such parameter thresholds have been used in previous works to define ORFans.

To estimate the mean level of nucleotide sequence similarity at the genome level between $P$. timonensis and Prevotella genomes available to date, we compared the only those ORFs only that could be found on the RAST server [31] with a query coverage of $\geq 60 \%$ and a minimum nucleotide length of $100 \mathrm{bp}$.

\section{Genome properties}

The genome is $3,169,464$ bp long with a $40.50 \%$ GC content (Table 3, Figure 5). Of the 2,802 predicted genes, 2,746 were protein-coding genes, and 56 were RNAs. A total of 1,795 genes (65.37\%) were assigned a putative function. 198 genes were identified as ORFans $(7,21 \%)$. The remaining genes were annotated as hypothetical proteins (673 genes $(24,51 \%))$. The remaining genes were annotated as either hypothetical proteins or proteins of unknown function. The distribution of genes into COGs functional categories is presented in Table 4. The properties and the statistics of the genome are summarized in Tables 3 and 4 .

Table 3. Nucleotide content and gene count levels of the genome

\begin{tabular}{lrr} 
Attribute & Value & \% $_{\text {of }}$ total $^{\mathbf{a}}$ \\
\hline Genome size (bp) & $3,169,464$ & 100 \\
DNA coding region (bp) & $2,758,009$ & 87.02 \\
DNA G+C content (bp) & $1,347,151$ & 42.50 \\
Total genes & 2,802 & 100 \\
RNA genes & 56 & 2.00 \\
Protein-coding genes & 2,746 & 98.00 \\
Genes with function prediction & 1,795 & 65.37 \\
Genes assigned to COGs & 1,479 & 53.86 \\
Genes with peptide signals & 678 & 24.69 \\
Genes with transmembrane helices & 540 & 19.66 \\
\hline
\end{tabular}

a) The total is based on either the size of the genome in base pairs or the total number of protein coding genes in the annotated genome. 


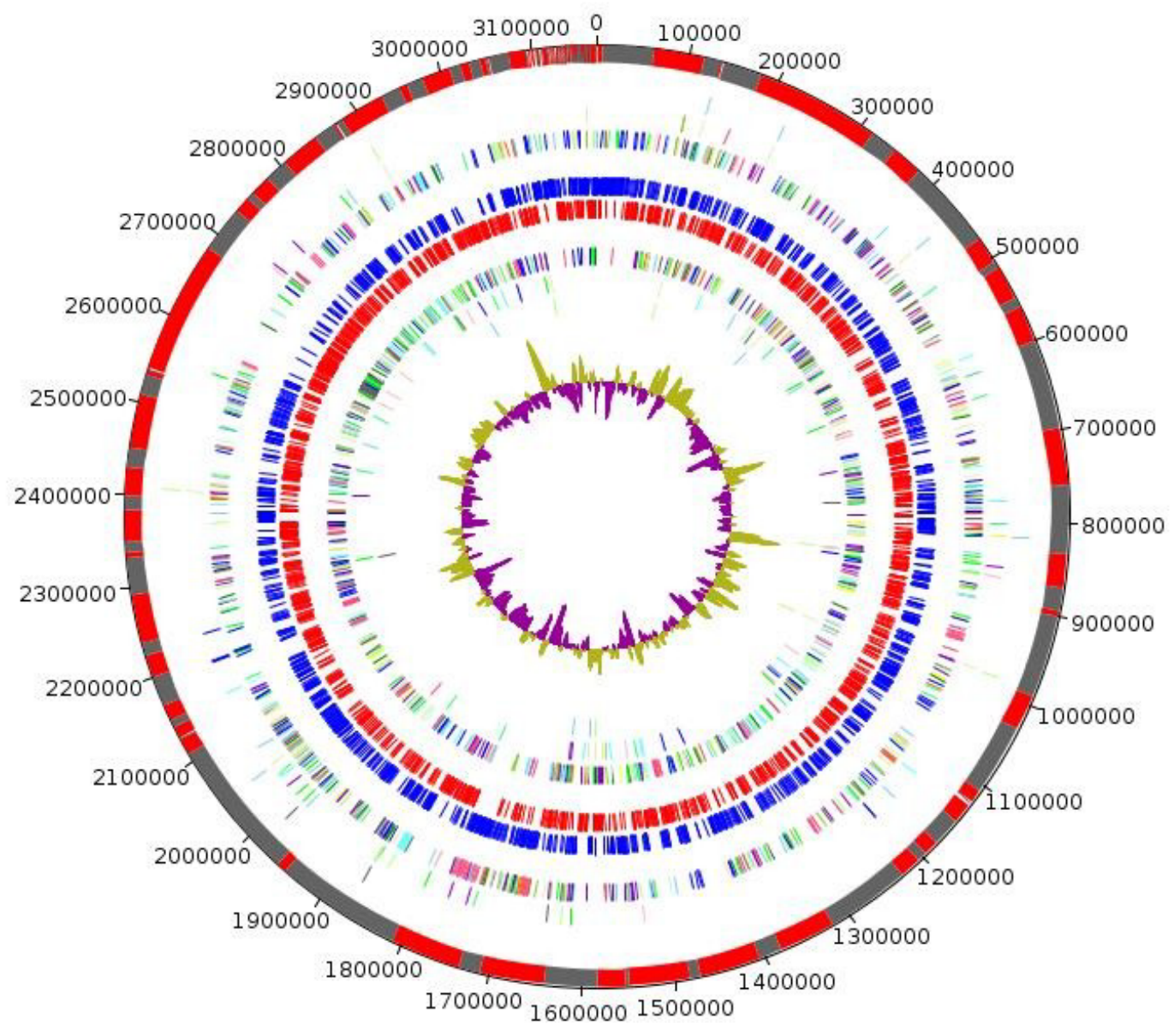

Figure 5. Graphical circular map of Prevotella timonensis genome. From outside to the center: Contigs (red / grey), COG category of genes on the forward strand (three circles), genes on forward strand (blue circle), genes on the reverse strand (red circle), COG category on the reverse strand (three circles), GC content.

\section{Comparison with other Prevotella genomes}

To date 33 genomes from species belonging to the genus Prevotella have been sequenced.

Whole genome sizes ranged between $2.42 \mathrm{Mb}(P$. bivia and $P$. amnii) and $3.62 \mathrm{Mb}$ (P. ruminicola). The $\mathrm{G}+\mathrm{C}$ content of the genomes was was between $36.5 \%$ for $P$. amnii and $55.9 \%$ for P. dentalis. $16 \mathrm{~S}$ rRNA gene sequence comparison was performed to obtain phylogenetic analysis of Prevotella species. A cluster including $P$. bergensis, $P$. dentalis, $P$. multisaccharivorax, $P$. buccae, $P$. baroniae, $P$. dentasini, $P$. denticola and $P$. multiformis was identified. From this group. the genomes of $P$. bergensis, $P$. dentalis, $P$. multisaccharivorax, $P$. buccae, $P$. denticola and $P$. multiformis have been sequenced. It is interesting to note that these genomes showed the highest $\mathrm{G}+\mathrm{C}$ contents (47.6-55.9\%) among the bacteria included in the genus Prevotella. A more in-depth study will allow us to determine if this group of bacteria represent a particular evolutionary lineage.

The genome of another strain of the species $P$. timonensis was sequenced, strain CRIS 5C B1. The genome of $P$. buccalis, which is the more closely related species to $P$. timonensis when $16 \mathrm{~S}$ rRNA encoding gene sequences were compared, has also been sequenced. $P$. timonensis strain $4401737^{\mathrm{T}}$ shared a mean sequence similarity of $96.45 \%$ (60.2$100 \%$ ) with P. timonensis strain CRIS 5C B1 and of 84.02\% (60-100\%) with P. buccalis.

The partition of the coding sequences into subsystems [31] is similar for the two genomes except for the transposable elements, whose numbers are significantly higher in strain $4401737 \mathrm{~T}$. 
Table 4. Number of genes associated with the 25 general COG functional categories

\begin{tabular}{|c|c|c|c|}
\hline Code & Value & $\%$ of total & Description \\
\hline$J$ & 135 & 4.92 & Translation \\
\hline A & 0 & 0 & RNA processing and modification \\
\hline K & 87 & 3.17 & Transcription \\
\hline $\mathrm{L}$ & 179 & 6.52 & Replication, recombination and repair \\
\hline B & 0 & 0 & Chromatin structure and dynamics \\
\hline $\mathrm{D}$ & 23 & 0.84 & Cell cycle control, mitosis and meiosis \\
\hline $\mathrm{Y}$ & 0 & 0 & Nuclear structure \\
\hline $\mathrm{V}$ & 44 & 1.60 & Defense mechanisms \\
\hline $\mathrm{T}$ & 42 & 1.53 & Signal transduction mechanisms \\
\hline M & 171 & 6.23 & Cell wall/membrane biogenesis \\
\hline $\mathrm{N}$ & 2 & 0.07 & Cell motility \\
\hline Z & 0 & 0 & Cytoskeleton \\
\hline W & 0 & 0 & Extracellular structures \\
\hline$U$ & 35 & 1.27 & Intracellular trafficking and secretion \\
\hline $\mathrm{O}$ & 73 & 2.66 & $\begin{array}{l}\text { Posttranslational modification, protein turnover, } \\
\text { chaperones }\end{array}$ \\
\hline $\mathrm{C}$ & 74 & 2.69 & Energy production and conversion \\
\hline G & 107 & 3.90 & Carbohydrate transport and metabolism \\
\hline $\mathrm{E}$ & 87 & 3.17 & Amino acid transport and metabolism \\
\hline $\mathrm{F}$ & 62 & 2.26 & Nucleotide transport and metabolism \\
\hline $\mathrm{H}$ & 62 & 2.22 & Coenzyme transport and metabolism \\
\hline I & 42 & 1.53 & Lipid transport and metabolism \\
\hline$P$ & 98 & 3.57 & Inorganic ion transport and metabolism \\
\hline Q & 12 & 0.44 & $\begin{array}{l}\text { Secondary metabolites biosynthesis, transport and } \\
\text { catabolism }\end{array}$ \\
\hline $\mathrm{R}$ & 206 & 7.5 & General function prediction only \\
\hline $\mathrm{S}$ & 80 & 2.91 & Function unknown \\
\hline$X$ & 1267 & 46.14 & Not in COGs \\
\hline
\end{tabular}

The total is based on the total number of protein coding genes in the annotated genome.

\section{Acknowledgements}

The authors thank Mr. Julien Paganini at Xegen Company for automating the genomic annotation process and

\section{References}

1. Glazunova OO, Launay T, Raoult D, Roux V. Prevotella timonensis sp. nov., isolated from a human breast abscess. Int I Syst Evol Microbiol 2007; 57:883-886. PubMed http://dx.doi.org/10.1099/ijs.0.64609-0

2. Euzéby JP. List of Bacterial Names with Standing in
Laetitia Pizzo, Audrey Borg and Audrey Averna for their technical assistance.

Nomenclature: a folder available on the Internet. Int J Syst Bacteriol 1997; 47:590-592. PubMed http://dx.doi.org/10.1099/00207713-47-2-590

3. Downes J, Wade WG. Prevotella fusca sp. nov. and Prevotella scopos sp. nov., isolated from the human oral cavity. Int J Syst Evol Microbiol 2011; 61:854858. PubMed 
http://dx.doi.org/10.1099/ijs.0.023861-0

4. Downes J, Tanner ACR, Floyd E, Dewhirst FE, Wade WG. Prevotella saccharolytica sp. nov., isolated from the human oral cavity. Int I Syst Evol Microbiol 2010; 60:2458-2461. PubMed http://dx.doi.org/10.1099/ijs.0.014720-0

5. Sakamoto M, Natsuko Suzuki N, Okamoto M. Prevotella aurantiaca sp. nov., isolated from the human oral cavity. Int / Syst Evol Microbiol 2010; 60:500-503. PubMed http://dx.doi.org/10.1099/ijs.0.012831-0

6. Downes J, Hooper SJ, Melanie J, Wilson MJ, Wade WC. Prevotella histicola sp. nov., isolated from the human oral cavity. Int / Syst Evol Microbiol 2008; 58:1788-1791. PubMed http://dx.doi.org/10.1099/ijs.0.65656-0

7. Downes J, Sutcliffe IC, Booth V, Wade WG. Prevotella maculosa sp. nov., isolated from the human oral cavity. Int J Syst Evol Microbiol 2007; 57:2936-2939. PubMed http://dx.doi.org/10.1099/ijs.0.65281-0

8. Downes J, Liu M, Kononen E, Wade WG. Prevotella micans sp. nov., isolated from the human oral cavity. Int J Syst Evol Microbiol 2009; 59:771-774. PubMed http://dx.doi.org/10.1099/ijs.0.002337-0

9. Hayashi H, Shibata K, Sakamoto M, Tomita S, Benno Y. Prevotella copri sp. nov. and Prevotella stercorea sp. nov., isolated from human faeces. Int J Syst Evol Microbiol 2007; 57:941-946. PubMed http://dx.doi.org/10.1099/ijs.0.64778-0

10. Lawson PA, Moore E, Falsen E. Prevotella amnii sp. nov., isolated from human amniotic fluid. Int I Syst Evol Microbiol 2008; 58:89-92. PubMed http://dx.doi.org/10.1099/ijs.0.65118-0

11. Alauzet C, Mory F, Carlier JP, Marchandin H, JumasBilak E, Lozniewski A. Prevotella nanceiensis sp. nov., isolated from human clinical samples. Int J Syst Evol Microbiol 2007; 57:2216-2220. PubMed http://dx.doi.org/10.1099/ijs.0.65173-0

12. Sakamoto M, Ohkusu K, Masaki T, Kako H, Ezaki T, Benno Y. Prevotella pleuritidis sp. nov., isolated from pleural fluid. Int I Syst Evol Microbiol 2007; 57:1725-1728. PubMed http://dx.doi.org/10.1099/ijs.0.64885-0

13. Tamura K, Peterson D, Peterson N, Stecher G, Nei M, Kumar S. MEGA5: Molecular Evolutionary Genetics Analysis using Maximum Likelihood, Evolutionary Distance, and Maximum Parsimony Methods. Mol Biol Evol 2011; 28:2731-2739. PubMed http://dx.doi.org/10.1093/molbev/msr121

14. Woese CR, Kandler O, Wheelis ML. Towards a natural system of organisms: proposal for the domains Archaea, Bacteria, and Eucarya. Proc Natl Acad Sci USA 1990; 87:4576-4579. PubMed http://dx.doi.org/10.1073/pnas.87.12.4576

15. Validation List No. 143. Int / Syst Evol Microbiol 2012; 62:1-4. http://dx.doi.org/10.1099/ijs.0.039487-0

16. Krieg NR, Ludwig W, Euzéby J, Whitman WB. Phylum XIV. Bacteroidetes phyl. nov. In: Krieg NR, Staley JT, Brown DR, Hedlund BP, Paster BJ, Ward NL, Ludwig W, Whitman WB (eds), Bergey's Manual of Systematic Bacteriology, Second Edition, Volume 4, Springer, New York, 2011, p. 25.

17. Krieg NR. Class I. Bacteroidia class. nov. In: Krieg NR, Staley JT, Brown DR, Hedlund BP, Paster BJ, Ward NL, Ludwig W, Whitman WB (eds), Bergey's Manual of Systematic Bacteriology, Second Edition, Volume 4, Springer, New York, 2011, p. 25.

18. Krieg NR. Order I. Bacteroidales ord. nov. In: Krieg NR, Staley JT, Brown DR, Hedlund BP, Paster BJ, Ward NL, Ludwig W, Whitman WB (eds), Bergey's Manual of Systematic Bacteriology, Second Edition, Volume 4, Springer, New York, 2011, p. 25.

19. Krieg NR. Family V. Prevotellaceae fam. nov. In: Krieg NR, Staley JT, Brown DR, Hedlund BP, Paster BJ, Ward NL, Ludwig W, Whitman WB (eds), Bergey's Manual of Systematic Bacteriology, Second Edition, Volume 4, Springer, New York, 2011, p. 85.

20. Shah HN, Collins DM. Prevotella, a new genus to include Bacteroides melaninogenicus and related species formerly classified in the genus Bacteroides. Int J Syst Bacterio/ 1990; 40:205-208. PubMed http://dx.doi.org/10.1099/00207713-40-2-205

21. Willems A, Collins MD. 16S rRNA gene similarities indicate that Hallella seregens (Moore and Moore) and Mitsuokella dentalis (Haapasalo et al.) are genealogically highly related and are members of the genus Prevotella: emended description of the genus Prevotella (Shah and Collins) and description of Prevotella dentalis comb. nov. Int I Syst Bacteriol 1995; 45:832-836. PubMed http://dx.doi.org/10.1099/00207713-45-4-832

22. Sakamoto M, Moriya Ohkuma M. Reclassification of Xylanibacter oryzae Ueki et al. 2006 as Prevotella oryzae comb. nov., with an emended description of the genus Prevotella. Int I Syst Evol Microbiol 2012; 62:2637-2642. PubMed http://dx.doi.org/10.1099/ijs.0.038638-0

23. Ashburner M, Ball CA, Blake JA, Botstein D, Butler $\mathrm{H}$, Cherry JM, Davis AP, Dolinski K, Dwight SS, Eppig JT, et al. Gene ontology: tool for the unification of biology. The Gene Ontology 
Roux, et al.

Consortium. Nat Genet 2000; 25:25-29. PubMed http://dx.doi.org/10.1038/75556

24. Prodigal http://prodigal.ornl.gov/

25. GenBank database. http:/www.ncbi.nlm.nih.gov/genbank

26. Tatusov RL, Galperin MY, Natale DA, Koonin EV. The COG database: a tool for genome-scale analysis of protein functions and evolution. Nucleic Acids Res 2000; 28:33-36. PubMed http://dx.doi.org/10.1093/nar/28.1.33

27. Lowe TM, Eddy SR. tRNAscan-SE: a program for improved detection of transfer RNA genes in genomic sequence. Nucleic Acids Res 1997; 25:955-964. PubMed http://dx.doi.org/10.1093/nar/25.5.0955

28. Lagesen K, Hallin P, Rodland EA, Staerfeldt HH, Rognes T, Ussery DW. RNAmmer: consistent and rapid annotation of ribosomal RNA genes. Nucleic Acids Res 2007; 35:3100-3108. PubMed http://dx.doi.org/10.1093/nar/gkm160

29. Krogh A, Larsson B, von Heijni G, Sonnhammer EL. Predicting transmembrane protein topology with a hidden Markov model: application to complete genomes. J Mol Biol 2001; 305:567-580. PubMed http://dx.doi.org/10.1006/jmbi.2000.4315

30. Bendtsen JD, Nielsen H, von Heijne G, Brunak S. Improved prediction of signal peptides: SignalP 3.0. J Mol Biol 2004; 340:783-795. PubMed http://dx.doi.org/10.1016/j.jmb.2004.05.028

31. Aziz RK, Bartels D, Best AA, Dejongh M, Disz T, Edwards RA, Formsma K, Gerdes S, Glass EM, Kubal $M$, et al. The RAST Server: Rapid Annotations using Subsystems Technology. BMC Genomics 2008; 9:75-89. PubMed http://dx.doi.org/10.1186/14712164-9-75 